\title{
Policy Analysis of Internal Quality Assurance System (Case study at Midwifery Major of Poltekkes Kemenkes Medan)
}

\author{
Rismahara Lubis \\ Lecture at Poltekkes Kemenkes Medan \\ North Sumatra, Indonesia
}

\author{
Eka Daryanto \\ Lecturer at Universitas Negeri Medan \\ North Sumatra, Indonesia
}

\author{
Restu \\ Lecturer at Universitas Negeri Medan \\ North Sumatra, Indonesia
}

\begin{abstract}
The purpose of this study was to analyze the policy of the Internal Quality Assurance System in the Midwifery Department of the Poltekkes Kemenkes Medan using the G.Edward C.III theory. The research method used is to use a policy analysis model approach according to George $\mathrm{C}$. Edward. The procedure of this research includes the steps: instrument preparation, data collection, data analysis, and report preparation. The research subjects were informants whose activities were directly related to quality assurance in the Polytechnic of the Ministry of Health, Medan. The method of data collection is done by giving questionnaires, documentation, and interviews. From the results of the study found: a) the form of communication in the implementation of accreditation policies and quality assurance in the Polytechnic Ministry of Health field has been running well, b) resources to support the accreditation policy is appropriate and applicable and the implementers of the policy, c) the disposition variable of the implementation has been good enough but still lack of support from the government and d) bureaucratic structure variables can have the availability of SOP (Standard Operating Procedures) which is clear in implementing accreditation policies and training certification in the health sector. Meanwhile, coordination between implementing agencies has been going well.
\end{abstract}

Keywords - policy analysis, quality assurance, poltekkes, ministry of health

\section{INTRODUCTION}

Higher education quality assurance is the process of planning, fulfilling, controlling, and developing higher education standards in a consistent and sustainable manner, so that the internal and external stakeholders of the tertiary institutions, namely students, lecturers, employees, community, business world, professional associations, government get satisfaction with the performance and output of higher education. Higher education quality is the compatibility between the organization of higher education with national education standards (SNP), as well as the standards set by the tertiary institutions themselves based on the vision and needs of the parties concerned [1].

Success in the presentation and absorption of knowledge is supported by the quality of educators, administrative services, facilities and infrastructure as well as other supporting infrastructures that are crucial. Of course, quality universities will be the first choice for prospective students to study. The benchmarks of the quality of the tertiary institution can be seen from the graduates who were printed whether they were able to compete in the workforce or instead only became educated unemployed [2].

Once the importance of quality for education, the government issued a Regulation through the Regulation of the Minister of Research, Technology, and Higher Education of the Republic of Indonesia No. 62 of 2016 concerning Higher Education Quality Assurance System which in article 2 states that the Directorate of Higher Education SPM aims to guarantee the fulfillment of Higher Education Standards systemically and sustainably, so that the culture of quality development, SPM Dikti functions to control the implementation of higher education by tertiary institutions to realize higher education quality.

It is very important to know how the implementation of the SPMI or Internal Quality Assurance System) policy in the Department of Midwifery, Poltekkes, Ministry of Health, Medan. An analysis study needs to be done whether the policy regarding the Internal Quality Assurance System has been implemented effectively and efficiently in the Midwifery Department of the Health Ministry of Health, Medan [3].

According to George C. Edward III in [4] suggested four variables that influence the implementation of policy, including; (a) communication, (b) resources, (c) dispositions, (d) bureaucratic structures. In terms of disposition, this includes the attitude of the implementers. Overall the implementation process in it there are three main activities, namely interpretation, organizing and application [5].

But in reality, from the results of several studies conducted by the internal quality assurance system in several universities, the results have not been as expected.

Based on the background described above, a special study is needed to obtain an overview of the process of implementing the Quality Assurance System at the Midwifery Department of the Polytechnic of the Ministry of Health and Medan and to determine what factors determine the success or failure of the implementation of the Quality Assurance System policy at the Department of Midwifery reviewed based on relevant theory.

\section{LITERATURE REVIEW}

\section{A. Internal Quality Assurance System}

SPMI is a systemic activity of higher education quality assurance by each tertiary institution autonomously or independently to control and improve the implementation of higher education in a planned and sustainable manner.

1) Principles of the Internal Quality Assurance System 
The SPMI principle is in accordance with the Higher Education Law and Permenristekdikti No. 62 of 2016 concerning SPM Dikti can be summarized as follows:

\section{- Autonomous}

SPMI is developed and implemented autonomously or independently by each tertiary institution, both at the level of the Study Program Management Unit (Departments, Departments, Schools, or other forms) or at the tertiary level

- $\quad$ Standardized

SPMI uses Dikti Standards consisting of SN Dikti set by the Minister and Dikti Standards set by each tertiary institution.

- Accuracy

SPMI uses accurate data and information on PD Dikti.

- Planned and Sustainable SPMI is implemented by using 5 (five) quality assurance steps, namely PPEPP Dikti Standards which form a cycle.

- Documented

Every step of PPEPP in SPMI must be written in a document, and documented systematically.

2) The Purpose and Function of the Internal Quality Assurance System

SPM Dikti aims to guarantee the fulfillment of Dikti Standards systemically and sustainably, so that quality culture grows and develops. one of the sub-systems of SPM Dikti, is:

- fostering and developing a culture of higher education quality;

- realize the vision and carry out the mission of higher education;

- a means to obtain accreditation status and ranks accredited by study programs and universities; and

- meet the needs of higher education stakeholders.

3) Implementation of the Internal Quality Assurance System

According to Article 3 paragraph (2) Permenristekdikti No. 62 of 2016 Regarding SPM Dikti, SPMI in a tertiary institution is planned, implemented, evaluated, controlled, and developed by the tertiary institution.Planning, implementing, evaluating and controlling, and developing SPMI in a tertiary institution, can be described as shown in Fig 1.

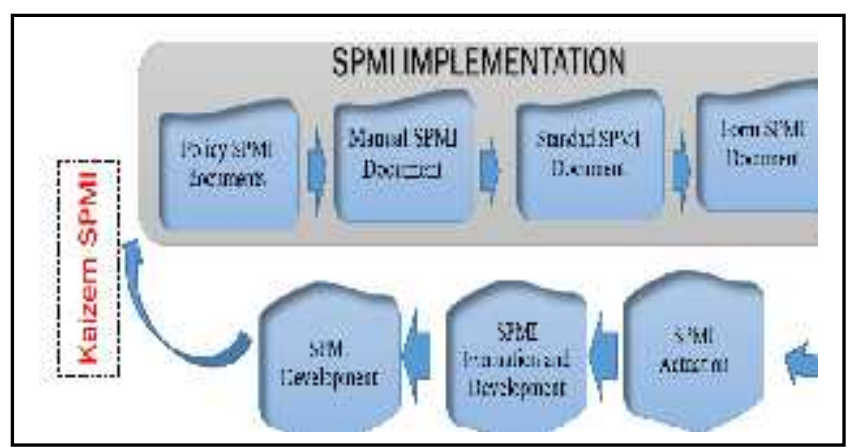

Fig 1. SPMI (IQAS) Implementation
Thus, the implementation of SPMI is an act of implementing SPMI in higher education institutions starting from:

- IQAS Planning

- Implementation of IQAS

- Evaluation and Control of IQAS

- IQAS Development

In [6] written that implementation of Standards in SPMI/IQAS (Dikti Standards) consists of a cycle that includes Determination, Implementation, Evaluation of implementation, Controlling implementation, and Improvement (PPEPP) Standards in SPMI (Dikti Standards) in Cyclus which can be seen in Fig 2 as follows:

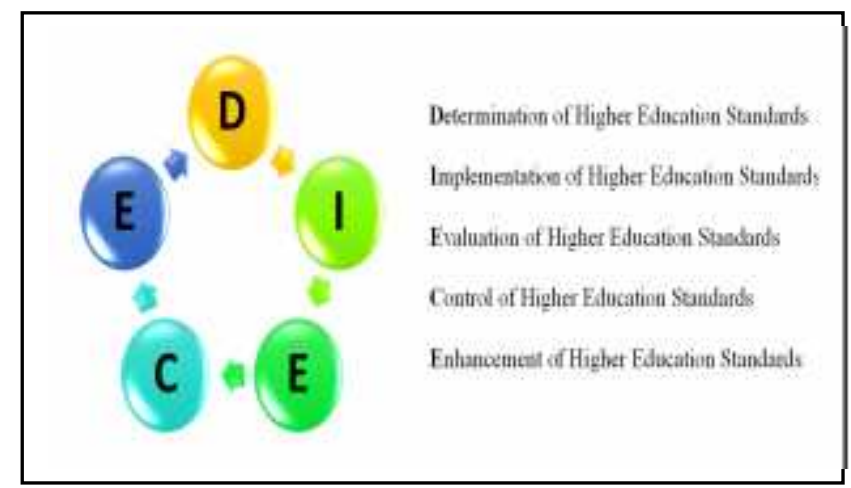

Fig. 2. Cyclus of SMPNI

\section{B. Analysis of Public Policy}

According to [7] public policy as a policy set by government agencies and officials. Although it is realized that public policy can be influenced by actors and factors from outside the government. The Process of Public Policy Analysis is a series of intellectual activities carried out in the process of political activities

1) Theory of Public Policy Implementation

George C. Edward III tries to answer these two questions by examining four factors or variables of policy, namely: (1) Communication, (2) Resources, (3) Disposition, (4) Bureaucratic structure. The four variables are also interconnected with each other.

a) Communication

Successful policy implementation requires that the implementor knows what needs to be done.

b) Resources

Even though the contents of the policy have been clearly and consistently communicated, if the implementor lacks the resources to implement it, the implementation will not be effective. .

c) Disposition

Disposition is the character and characteristics possessed by the implementor, such as commitment, honesty, democratic nature.

d) Bureaucratic Structure

The organizational structure in charge of implementing the policy has a significant influence on the implementation of the policy. 
Schematically, the implementation of public policy analysis can be seen in the figure below. The existence of interrelationships between each variable that affect each other reciprocally.

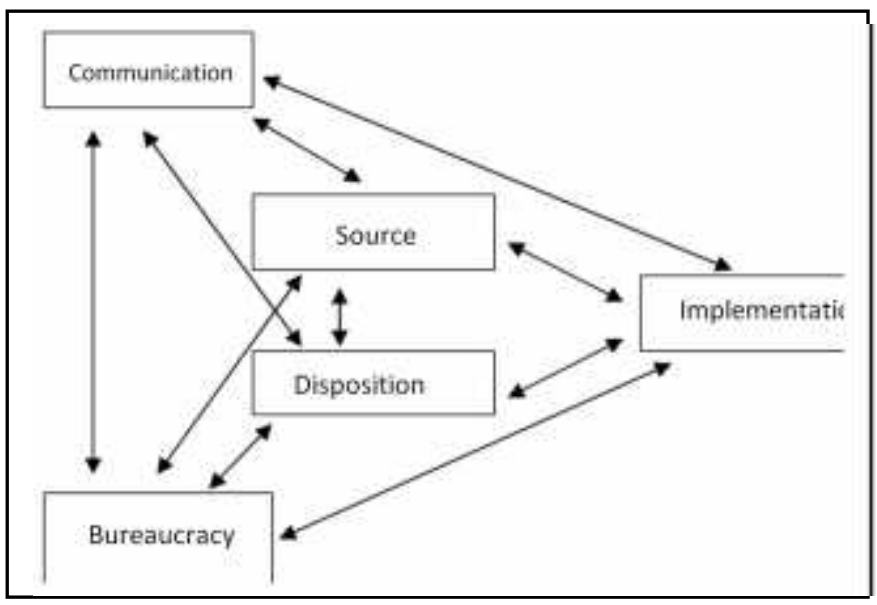

Fig 3. Theory of Donald S. Van Meter \& Carl E Van Horn (1975) Source:Public Analysys Policy of Subarsono[8]

\section{METHODOLOGY}

This study uses an evaluation method with a quantitativequalitative descriptive approach. Steps: setting quality standards, implementing quality standards, evaluating the implementation of standards, controlling the implementation of quality standards and improving quality standards using a policy analysis model approach according to George $\mathrm{C}$. Edward who argues that there are 4 variables that affect public policy, namely: Communication, resources, disposition and bureaucratic structure. The procedure of this research includes the steps: instrument preparation, data collection, data analysis, and report preparation.

The subjects of this study were the Head of the Department and the management element in the Midwifery Department of the Health Ministry of Health, Medan. A full description of the research subjects is presented in the following table:

TABLE 1. RESEARCH SUBJECTS

\begin{tabular}{|c|l|c|}
\hline No & Research Subjects & Total \\
\hline 1 & head of program & 1 person \\
\hline 2 & Department Secretary & 1 person \\
\hline 3 & Head of Study Program & 2 persons \\
\hline 4 & Academic Administration & 1 person \\
\hline 5 & Student affairs & 1 person \\
\hline 6 & Laboratory unit & 1 person \\
\hline & TOTAL & 7 people \\
\hline
\end{tabular}

\section{RESULTS AND DISCUSSION}

\section{A. Policy analysis results}

1) Communication

Policy communication is the process of delivering information from communicators to policy implementers [9]. From the research results obtained:
- Transmission of policies that constitute decisions and orders must be forwarded to implementors, target groups and other interested parties, both directly and indirectly.

- Clarity of intention is that the policy transmitted to implementers, target groups and other interested parties, both directly and indirectly, can be clearly received so that all of them know what the intentions, goals, objectives and substance of the policy are

- Consistency and Clarity. If a policy is to run effectively, the implementation instructions must be consistent and clear.

2) Resource

If the policy implementation instructions have been clearly and consistently passed on, but if they are not supported by resources then the policy implementation is not effective. Resources referred to in the implementation of the accreditation and certification of training programs in the health sector are policy instruments, human resources and authority. Based on the research results obtained:

- For existing policy instruments are in the form of Government Regulations, Minister of Health Decrees, manuals, Implementation Guidelines

- Human resources are one of the variables that influence the success or failure in implementing a policy [9].

- According to [10], failures in policy implementation often occur because of insufficient, inadequate or incompetent staff in their fields

- According to Edwards in [9], Authority is a formal authority granted to policy implementers. As actors in implementing policies, human resources must have the authority to carry out these policies

3) Disposition

According to Edwards in [9], disposition is the will, desire and inclination of policy actors to carry out policy seriously so that what is the policy objective can be achieved. The disposition referred to in this study is the commitment of implementers and incentives received by the implementers of policies. From the research results obtained:

- Commitment. Commitment is the attitude or willingness shown by the implementers of the accreditation policy and training certification in the health sector has been seen high.

- Incentives. Incentives can be positive or negative. Positive means that policy implementers are rewarded for successfully carrying out their duties. Negative means that the violator can be penalized if found violating the rules. In implementing the accreditation policy and training certification in the health sector the policy implementers are given incentives in the form of team salaries from the DIPA Pusdiklat Apparatus.

4) Bureaucratic Structure

- Policy management SOP is defined as a mechanism or working order of policy implementation formally written in a clear, 
systematic and straightforward framework. The implementation of accreditation policy and training certification in the health sector has been going well.

- Coordination between implementing agencies Responsibility in implementing a policy is often spread among several organizations, so that it requires intensive coordination between the implementing institutions of the policy.

\section{B. Discussion}

According to Edwards, in [5], the study of policy implementation is very important for Public administration and public policy. Implementation of policies is one stage of public policy making, between the formation of policies and the consequences of policies for the community.

The implementation of the Accreditation and Quality Assurance Policy at the Medan Ministry of Health Poltekkes is influenced by important variables, including: communication, resources, disposition, and bureaucratic structure.

\section{1) Communication}

Communication is a very important part in achieving the goals and objectives of implementing a public policy. A policy will work well if effective communication occurs between program implementers and the groups that are the target of the policy. In addition, decision makers and implementers in the field already know and understand what they are doing clearly and know why the policy was made.

According to Edwards' view in [9], public policy information needs to be conveyed to policy actors so that policy actors can know, understand what is the content, goals, directions, policy target groups so that policy objectives and objectives can be achieved in accordance with what is clearly expected and consistent. If the goals and objectives of the policy are unclear or not known at all by the target group, it will cause resistance from the target group.

a) Transmission

According to Edwards in [9] the first requirement for effective policy implementation is transmission that requires that policies in the form of decisions and orders must be passed on to the policy implementor but also to the target group and other interested parties, both directly and indirectly towards the policy. What are the goals and objectives of the policy must be transmitted well so that it will reduce the distortion of policy and program implementation.

In this research, it is known that the results of the socialization carried out are seen with the increasing number of proposing units that apply for training accreditation before organizing training in order to guarantee the quality of training as well as training providers in their health.

b) Clarity

According to Edwards in [5], it was explained that often the instructions that were passed on to the implementers were blurred. The ambiguity of the communication message conveyed regarding the implementation of the policy will lead to wrong interpretations and may even conflict with the original meaning. The ambiguity of policy communication messages does not always impede implementation. Therefore, the communication received by the implementers of the policy must be clear and not confusing[10].

c) Consistency

The instructions given in carrying out a communication must be consistent and clear. Orders that often change will cause confusion from the executor in the field.

The results showed that the instructions in the accreditation policy and training certification in the health sector have been carried out consistently and clearly in accordance with the Decree of the Minister of Health No. 725 of 2003 [3]. However, in implementing this policy there are still deviations made by several institutions that want to quickly in a practical sense which considers its competence to be in the institution by conducting training without accrediting its training first. Nevertheless, some of the implementers of accreditation and certification policies have consistently carried out the commands of the policy, this can be seen from the large number of training providers who have proposed accreditation and certification as a form of communication consistency.

\section{2) Resources}

Although the instructions contained in the policy have been forwarded clearly, carefully and consistently, but if the implementers lack the resources needed to implement the policies, then even this implementation tends ineffective.

Failures in implementing policies often occur because staff are inadequate, inadequate, or incompetent in their fields. Increasing the number of staff and implementors alone is not sufficient, but it also requires sufficient staff with the expertise and abilities (competencies) needed to implement the policy or carry out the tasks desired by the policy itself [10].

3) Disposition

a) Commitment

According to Edwards in [9], Disposition is a tendency, desire or agreement of the implementers. If the implementation of a policy is to succeed effectively and efficiently, policy implementers not only know what needs to be done and have the ability to carry out the policy, but they must also have the will to implement the policy.

b) Incentives

According to Edwards in [11] one way to motivate the implementers to implement the policy is by providing incentives, both in the form of certain benefits and costs.

\section{4) Bureaucratic Structure}

In organizational governance the workflow is a guideline for members of the organization in carrying out daily activities in order to obtain the same attitudes and perceptions of all elements in achieving predetermined organizational goals. One of the important structural aspects of every organization is the existence of standard operating procedures (standard operating procedures) and clear, straightforward from start to finish. 


\section{a) Policy Management}

Good governance is a process that is implemented in government organizations in implementing policies. This good governance even though it cannot guarantee the implementation of policies runs appropriately, but if adhered to clearly can reduce the abuse of power.

b) Coordination between implementing agencies

The results showed that coordination between institutions had been carried out continuously in the implementation of accreditation and certification. For trainings where the planning is made at the center, when accreditation has been carried out at the center then the training will be held at the regional level. They do not need to accredit the curriculum component, because it is a national curriculum, maybe what needs to be accredited is the training, participants and implementation. For example the Apparatus Training Center trained the Provincial Accreditation Team.

\section{CONCLUSION}

From the description of the results of the study to the discussion conclusions can be drawn as follows:

1) Based on an analysis of communication variables in the implementation of accreditation policies and training certifications in the health sector, it has been running well. This can be seen from the number of program units and training providers applying for accreditation every year.

2) Based on the analysis of resource variables, it is known that the instruments used to support the accreditation and certification policy are appropriate and applicable and the policy implementers have full authority or authority in implementing accreditation and certification policies in the health sector.

3) In terms of competence and the amount of human resources as the executor of the policy it is known:

- The central accreditation and certification team has competencies that are in accordance with the standards.

- Lack of competence and understanding of human resources from the Department of Health, Hospitals and other Ministries that conduct training in the health sector on the implementation of accreditation and certification policies in the health sector.

4) Disposition. The results of research and analysis of the disposition variable, it appears that the commitment of the executor is very high to implement but the lack of support from the government in this case the Ministry of Health through the Apparatus Training Center to increase their motivation in implementing this policy in the form of a clear incentive or reward system. While the provisions regarding administrative sanctions have been carried out in accordance with article 10 of the Ministry of Health 725 of 2003.
5) Bureaucracy. Based on the analysis of bureaucratic structure variables, it can be concluded that the availability of SOP (Standard Operating Procedures) is clear in implementing accreditation policies and training certifications in the health sector. Meanwhile, coordination between implementing agencies has been going well.

\section{ACKNOWLEDGMENT}

I would like to express my soecial thanks to all tpersen who interfere me to finish this research. First, to Dr. Eka Daryanto and Dr. Restu who guided me setting this study. Second I say thanks to my friend Din Oloan Sihotang as a best friend to discuss this research both theory and implementation. And the last to AISTEEL committee/Riviewers to accept this paper published.

\section{REFERENCES}

[1] Peraturan Menteri Riset, Teknologi, dan Pendidikkan Tinggi Republik Indonesia No. 62 tahun 2016 tentang Sistem Penjaminan Mutu Pendidikan Tinggi

[2] Basuki Sumarno, 2013, Analisis Implementasi Sistem Penjaminan Mutu Dan Akreditasi Pada Program Studi Pendidikan Jasmani Kesehatan Dan Rekreasi Fakultas Keguruan Dan Ilmu Pendidikan Universitas Lambung Mangkurat Banjarmasin, Jurnal Multilateral Vol. 12 No. 2 Desember 2013Badan Perencanaan Pembangunan Nasional, (2005) Kajian Kebijakan Perencanaan Tenaga Kesehatan, 2005

[3] Pusdiklat SDM Kesehatan, Standar Sumber Daya Pelatihan, Depkes, 2009 Undang-undang Nomor 43 Tahun 1999 tentang Perubahan Undang-undang Nomor 8 Tahun 1974 Tentang Pokok-pokok Kepegawaian Undang - undang Nomor 36 Tahun 2009 tentang Kesehatan

[4] Mulyadi Deddy, 2013, Studi Kebijakan Publik Konsep dan Aplikasi Proses Kebijakan Publik Berbasis Analisis Bukti untuk Pelayanan Publik, Alfabeta, Bandung.

[5] Winarno, Budi, 2002, Teori dan Proses Kebijakan Publik, MedPress, Yogyakarta.

[6] Koran Jakarta, Digital Edition, "Kualitas Lulusan Perguruan Tinggi Indonesia dan Mengangkat Kembali 'Link and Match",, 31 Agustus 2012, dapat diakses di http://koranjakarta.com/index.php/ detail/view01/99485

[7] Anderson, James E., 1973. Public Policy Making, New York: Holt, Renealt and Winston.

[8] Subarsono, AG (2005). Analisis Kebijakan Publik: Konsep, Teori dan Aplikasi, Yogyakarta: Pustaka Pelajar

[9] Widodo, Joko (2006). Analisis Kebijakan Publik: Konsep dan Aplikasi Analisis Proses Kebijakan Publik. Bayumedia Publishing

[10] Indiahono, Dwiyanto. 2009. Kebijakan Publik Berbasis Dynamic Policy Analisys. Gava Media: Yogyakarta

[11] Nawawi, Ismail. 2009. Public Policy, Analisis, Strategi Advokasi Teori dan Praktek. Surabaya: PMN 